\title{
KNOWLEDGE MANAGEMENT AND ORGANIZATIONAL PERFORMANCE: THE NEGLECTED ROLE OF INSTITUTIONAL ACCOUNTING PRACTICES
}

\author{
Ozavize Freida Ayodele* \\ Faculty of Business and Management, UCSI University, Kuala Lumpur, Malaysia
}

Liu Yao

Faculty of Management Engineering, Huaiyin Institute of Technology, Huai'an Jiangsu, China

\author{
Hasnah Binti Haron \\ Faculty of Economics and Muamalat, Universiti Sains Islam Malaysia, Bandar Baru Nilai, \\ Negeri Sembilan, Malaysia \\ Hooi-Cheng Eaw \\ Faculty of Business and Management, UCSI University, Kuala Lumpur, Malaysia
}

\begin{abstract}
The study highlights the part of institutional accounting practices in the relationship between specified KM capabilities and institutional performance. A theoretical model was tested based on the insight from literature and knowledge-based theory (KBT). The data collected from a survey of 322 staff in knowledge-based organizations (KBOs) were analyzed to test the extended model using partial least squares structural equation modeling approach. The result depicts that greater levels of specific KM infrastructure and process capability would positively influence institutional accounting management practices and, consequently organizational performance. Unlike KM process capability, KM infrastructure capability has a positive and significant impact on organizational performance. The study provides a new understanding to management and practice on the vital role played by institutional management accounting practice in KM success in Malaysia. The research offers fresh insight into further studies in diverse settings. The research is insightful as it deviates from the over-researched context in KM literature to extricate the role of accounting in the business KM strategy.
\end{abstract}

Keywords: Knowledge management capability; institutional management accounting practices; organization performance; knowledge-based organization

Received: 8 December 2019

Accepted: 27 September 2021

https://doi.org/10.33736/ijbs.4327.2021

\footnotetext{
* Corresponding author: Department of Accounting and Finance UCSI University, 1 Jalan Menara Gading UCSI Height, Cheras 56000, Kuala Lumpur, Malaysia; Email: freida.ayodele@yahoo.ca
} 


\section{INTRODUCTION}

Accounting makes visible and calculable the matters and activities that are at the focus of management and diverse stakeholders (Ball \& Brown, 2013; Cuganesan et al., 2012). A reliable accounting information system facilitates institutions' capacity to manage resources, compete, attract finance and take advantage of market opportunities to improve performance (Grabski et al., 2011; Ozdil \& Hoque, 2017; Spathis et al., 2004; Tsahurudu \& Carnegie, 2018). As accounting perform a crucial mediating role in organizations (Appelbaum et al., 2017), organizations depend on the information emanating from the institutional accounting information system to achieve several competing goals. Thus, confirming the privileged position and importance of accounting practices in institutions

Just like the institutional accounting information system, equally important to institutions in this dispensation for enhanced performance is knowledge management (KM). Drawing from Alavi \& Leidner (2001), KM is a dynamic strategy of facilitating institutional performance by maximizing the knowledge that is embedded and shared among employees. In line with Alavi and Leidner, (2001), Sveiby 2001 argued that it is the knowledge possessed by staff that creates value in organizations and should begin KM strategy. Similarly, Hitt et al. (2016) pointed out that the performance of an overall institution is a direct product of human capabilities. Interestingly, accounting is not an exception on the importance of knowledge as what makes accounting practice effective or not in providing relevant financial advice via accounting information is mainly dependent on the deep expertise possessed by the accountants. As the competence of people and the procedures for improving their ability are the vital ingredient in KM strategy formulation (Sveiby, 2001; Zahra \& George, 2002), the scope of KM in this study is limited to KM infrastructure capability (KMI), that is employee competence, and KM process capability (KMP), that is knowledge related processes available for enhancing staff knowledge. Contrary to prior studies that considered KM capabilities at the teamed level (Lee \& Choi, 2003; Zaeid 2012; Ayodele et al., 2019), investigated in this research are individual KM infrastructure and process capability perspective (Fan et al., 2009; Mills \& Smith, 2011; Pandey \& Dutta, 2013). Studying the unique impact of each of the specified KM capabilities would enhance decision-making at the level. Compared with aggregating the capabilities, the indirect effect of each of the KM capability via institutional management accounting practices can be easily understood and determined.

Most of the works in the literature provided empirical results on the observed relationship existing between KM capabilities and organization performance (Lee \& Choi, 2003; Lee \& Lee, 2007; Mao et al., 2016; Moon \& Lee, 2014; Zaied, 2012). Although insight from the works in literature can be drawn upon, nevertheless, whether institutional accounting practices underlies KM effect on organization performance is under-researched. Particularly in Malaysia, empirical research examining institutional accounting information system as mechanisms through which the decomposed KM capabilities influences institutional performance is scarce (Zaied, 2012; Eréndira et al., 2017; Low \& Ho, 2016; Zoogah et al., 2015). As KM investigation in organizations is not currently tailored towards institutional accounting practices (Cepeda \& Vera, 2007; Ayodele et al., 2019), it is difficult to comprehend the practice involvement in organization KM strategies and investigating the role played by the practice in KM matters becomes worthwhile. Otherwise, the knowledge of the possible contributions of institutional accounting role in organizational KM success story would remain obscure especially now that the focus of KM in organizations is not currently on institutional accounting practice. 
The study seeks to ascertain the direct influence of specific KM capabilities (KMI and KMP) on organization performance. The second intention of the research is to examine if the relationship between decomposed KM capabilities and overall institutional performance is explained by institutional accounting practices to extricate the practice possible role in KM success. That is to test whether higher levels of distinctive KMI and KMP would positively influence institutional management accounting practices and, consequently organizational performance. Lastly, if there are observed indirect relationships between specific KMI, KMP, and organizational performance, the study would further investigate the nature of mediation relationships that emphasizes the practice role in institutional KM strategies.

The study is significant as it introduces an under-researched explanatory variable to make clear the possible contributions of established management accounting system in the relation between KM and institutional performance. As the role of accounting in organization KM effort is not well substantiated, the study, therefore, draws the attention of institutions, academics, professionals, and various stakeholders on how accounting practices enable KM actions. Consequently, more pragmatic, and insightful research that incorporates and credits the contributions of accounting profession in business KM models can spring up for more impressive KM benefits, implementation and strategic decision making. As business owners and management largely depend on the information output of their internal accounting function for important insight, the research may inform them on the KM perspective that would positively influence the information capability of their strategic accounting functions. Furthermore, based on the individual KM perspective taken in the study, the research makes it easier to assess the indirect distinctive antecedents of KM capabilities on organizational performance at such a decomposed level. To evade patchy conclusions, the study employs the knowledge-based theory (KBT) while drawing insights from empirical works to test the mediating role of institutional accounting practices.

\section{LITERATURE REVIEW AND DEVELOPMENT OF HYPOTHESES}

Knowledge (know what and know-how) is the institution's most important resource (Grant, 1996; Liu \& Abdalla, 2013; Ramjeawon \& Rowley, 2017). The reason is that expertise provides the most excellent ability to sustainable differentiation that culminates in superior performances in organizations (Zaied, 2012; Nieves \& Haller, 2014; Ramachandran et al., 2013). Interestingly, past studies define organizations as bodies that produce, integrate, and allocate knowledge based on the knowledge-based theory (KBT) of the firm (Grant, 1996; Sveiby, 2001; Low \& Ho, 2016; Nonaka et al., 2018). A knowledge-based strategy is an approach that studies KM with particular importance placed on the intangible knowledge resource, specific knowledge capability or embedded expertise in institutions processes and infrastructures (Sveiby, 2001; Nieves \& Haller 2014; Martín-de Castro, 2015). Process capabilities because insight from the literature (Darroch, 2005; Olaisen \& Revang, 2018) shows that it is not sufficient for organizations to have employees with the requisite knowledge as infrastructure, but it is also necessary for them to possess the capacity to convert the knowledge in a process to influence organizational performance.

Also, Zahra and George (2002) and Nonaka et al. (2018) argued that employee involvement in knowledge-based process activities like application, conversion, sharing, communication, and assimilation helps them to create value. It is important to recall that KM process capability (KMP) covers knowledge-related processes provided by the organization to assist the employee in making 
their knowledge useful to the organization. Defined as KM infrastructure capability (KMI) in this study is the knowledge competence possessed by individual employees in organizations. In line with prior studies and KBT that specifies KM infrastructure and process capabilities as essential KM components, KM infrastructure capabilities (KMI) and process capabilities (KMP) are the two independent variables considered in the study. Apart from the defining important variables, the KBT is the theory drawn upon in the study to define the hypothesized relationships between variables. Using KBT as an offshoot of resource-based theory (RBT), prior studies argued that KM processes and infrastructure capabilities (Sveiby, 2001; Karadsheh et al., 2009; Masa'deh et al., 2017; Pee \& Kankanhalli, 2016; Zaied, 2012; Zheng et al., 2010) have positive and remarkable influence on firm performance. Therefore, expected in this study is that KM infrastructure capability (KMI) as knowledge input resource and process capability as knowledge process resource would separately impact organizational performance (OP) as a dependent variable in this study.

\section{H1: KMI positively influences $O P$}

\section{H2: KMP positively influences $O P$}

$\mathrm{KM}$ is a new management practice in this era. Linked to the improved performance of information systems in organizations of which accounting information system is a core aspect is KM (Al-Emran et al., 2018). Also, organization strategy has been proposed in the literature to influence effectiveness and management accounting practices (Abdel-Kader \& Luther, 2008; Abu Taber et al., 2014; Al-Emran et al., 2018; Cuganesan et al., 2012; Guzzo \& Dickson, 1996; Hackman \& Morris, 1975). Sveiby (2001) argued that a knowledge-focused strategy influences financial information capability as an outcome in organizations. As KBT illustrates a positive relationship between knowledge input resource, knowledge process, and outcomes, thus examined individual KM strategies in this context are expected to positively affect institutions management accounting practices. Nonetheless, Abdel-Kader and Luther (2008) and Ayodele et al. (2019) empirically argued the importance of examining the effect of emerging KM practice on institutional accounting practices mechanisms in organizations. In this study, it is important to note that institutional accounting practice is referred to as the capacity of accounting information system (accountants, processes, techniques, etc) to provide relevant and reliable accounting information that supports decision-making and control in the organization (Abdel-Kader \& Luther, 2008; Kanellou \& Spathis, 2011; Tilahun, 2019).

Kanellou and Spathis (2011), Shang and Seddon (2002), and Spathis and Ananiadis (2005) indicated that derived from large organizations sophisticated management accounting practices are core benefits like operational related benefits. Accounting practice underlies and enables organizational action (Tsahurudu \& Carnegie, 2018). Appelbaum et al. (2017) argued that accounting performs mainly mediating roles in organizations and have linked this role to organization performance. Similarly, Cuganesan et al. (2012), Fagbemi et al. (2016) and Howieson (2003) indicated that institutions could actualize their research and non-research based goals due to instituted strategic accounting practices. As institutional accounting practices serve as mediums through which organizational objectives are achieved, thus, an indication that the practice can intermediate KM capabilities impact on organization performance. Accounting is the information system that provides direct knowledge outcome that is valuable and non-substitutable in 
institutions. Therefore, this study suggests the practice as an essential knowledge related resource or capability performing important roles in organizations.

Theoretically, KBT suggests that knowledge input and process resource influence on an outcome can be indirect. That is, in additition to the direct influence on an outcome, a possible mediating variable underlies the impact of KMI and KMP on an outcome. More so, authors like Andreeva and Kianto (2012), Darroch (2005), Lin and Wu (2014), and López-Nicolás and Meroño-Cerdán (2011) while drawing from KBT capability perspective have evidenced the possibility of an intermediate variable resource mediating the influence of knowledge input and process capabilities on an independent variable. The study prescribes IAP as a mediating mechanism through which individual KM capabilities (infrastructure and process) could affect overall institutional performance (OP). Thus, consistent with KBT, the study expects that greater levels of specific KMI and KMP would positively influence IAP and, consequently OP. Furthermore, the study expects a possible mediating relationship to exist if IAP underlies the impact of individual KMI and KMP on OP. Based on the above discussions and in line with the research intentions, further hypotheses the study seek to test are as follows:

\section{H3: KMI positively influences IAP and, consequently $O P$}

\section{H4: KMP positively influences IAP and, consequently $O P$}

Figure 1 illustrates the summary of the hypothesized direct and indirect effects of KM infrastructure capabilities (KMI), and KM process capabilities (KMP) on organization performance (OP) via institutional accounting practices (IAP). The four hypotheses are tested in the next section.

Figure 1: The Research model

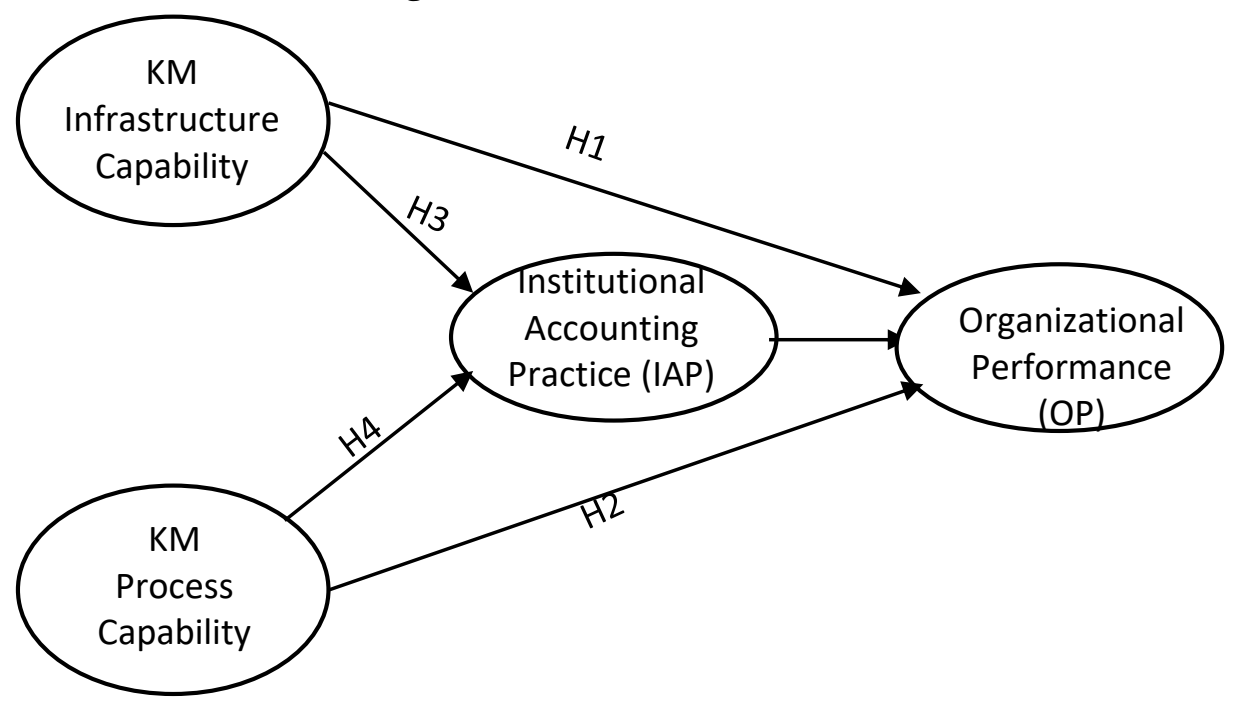




\section{METHODOLOGY}

Administered with the aid of a contact person in each of the organizations and volunteers in the study is the 426 structured questionnaires comprising of close-ended questions. The sample consists of purposive sampling of respondents at various management levels from five largely populated knowledge-based organizations (KBOs) in Malaysia. Drawing from authors like Zack (2003) on KBOs, institutions of higher learning is typified as KBOs in this context of the study. Only knowledge-based organizations are recognized because of their high level of involvement in knowledge-related infrastructures and process activities. Thus, they are expected to be knowledgeable and give an expert opinion on KM matters like this study. Besides, the KBOs in Malaysia contribute primarily to the growth and development of the country's knowledge economy and have resources to adopt sophisticated management accounting practices (Abdel-Kader \& Luther, 2008). Out of the distributed questionnaires, 340 questionnaires were returned. After deleting 18 cases, 322 questionnaires were used in the main analysis of which two-third of the respondents are females while one-third represent the males. The sample of 322 utilized for the study is adequate since it is above the threshold of 200 recommended in structural equation modeling (SEM) literature Hair Jr et al. (2014). Also, using sample size calculation based on the moderate effect size of 0.30 , with an alpha of 0.05 and power of 0.95 in G-power analysis version 3.0 , suggest the adequacy of the sample size 322 utilized in the study.

\subsection{Measures}

The variables of this research are measured using multi-item scales validated in past studies. Items for KM infrastructure capabilities (KMI) are developed based on the analysis of Lee and Choi (2003) and Sveiby (2001). Derived from the existing instruments of Darroch (2005), Zahra and George (2002), Lin (2014), and Zaied (2012) is KM process capabilities (KMP) scale. Adapted from Abdel-Kader and Luther (02008), Shang and Seddon (2000), Sirmon et al. (2008), Spathis and Ananiadis (2005), and Spathis et al. (2004) is institutional management accounting practice (IAP) items of measure. Lastly, organization performance is developed based on the works of Gold et al. (2001), Hackman and Morris (1975), Hitt et al. (2016), Lee and Choi (2003), and Lin and Wu (2014). A 5-point Likert scale ranging from (1) strongly disagree to (5) strongly agree, is used with due consideration given to the coding to fulfill the prerequisite of equidistance rule necessitated in every structural equation modeling study as indicated in Hair Jr et al. (2017). Before the final survey, a pre-test was conducted to confirm that the questions were understood, minimize inexactness and to provide content validity.

\subsection{Analysis}

The research employs the Statistical Package for Social Sciences (SPSS) version 23.0 to screen the data before the primary data analysis. Employing the Shapiro-Wiki test, the preliminary investigation shows that the data is not normally distributed. For the main data analysis, the partial least squares structural equation modeling (PLS-SEM), SMART PLS version 3.0 is employed to test the hypothesized relationships in the research model beginning with the estimation of the measurement model, and lastly, structural model assessment. In assessing the measurement model in this study, the reflective measurement evaluation reliability and validity criteria are applied. According to Hair Jr et al. (2017), the key criteria for reflective measurement model evaluation include the assessment of indicator reliability using indicator loadings, internal consistency 
reliability employing composite reliability $(\mathrm{CR})$ as a criterion, convergent validity, and discriminant validity.

Going by the reflective measurement guidelines, discriminant validity is assessed using the Henseler et al. (2015) heterotrait-monotrait ratio (HTMT) of correlations. The reason is that neither Fornell-Larcker criterion nor cross-loadings approach can reliably detect discriminant validity problems as indicated in Henseler et al. (2015). Also, the convergent validity which assesses the extent to which a measure correlates positively with alternative measures of the same constructs was evaluated using average variance extracted (AVE) as a criterion in the study. Based on the outcome of the construct validity and reliability assessment of the measurement model, the second stage in the PLS-SEM approach which is the assessment of the structural model is conducted in the study. Drawing from Hair Jr et al. (2017), the estimation of the structural model in this study involves the 5000 bootstrapping procedure to test the significance of the hypothesized relationships. Before examining the link in the structural model, this study assessed the level of collinearity as the coefficient of the independent variables might be biased against the predictor constructs (Hair Jr et al., 2017). The threshold employed is less than 5.0 as Hair Jr et al. (2017) indicated that a variance inflation factor (VIF) of 5.0 or higher portrays a potential collinearity problem among the constructs. The study assumes an error of 5\% and a confidence level of $95 \%$.

In analyzing IAP as a mediating variable, this study draws on testing the significance of the direct and indirect effects via bootstrap sampling procedure recommended by Hair Jr et al. (2017) and Sarstedt et al. (2017) since it is more suitable for mediation analysis compared to other existing approaches like the Baron and Kenny approach. Hair Jr et al. (2017) argued that for mediation to occur, an indirect relationship must exist between the independent variable and the dependent variable. That is, there must be a direct relationship between the independent variable and the mediating variable on the one hand, and another direct relationship between the mediating variable and the dependent variable on the other hand. The individual indirect relationship is then compared with the specific direct relationship to arrive at the nature of the mediation relationship.

\section{RESULTS}

\subsection{Evaluation of the Measurement Model}

Figure 2 depicts the measurement model. In assessing the discriminant validity, the result (See Table 1) depicts that all the HTMT values are lower than the recommended threshold of 0.90 and the HTMT confidence level values are significantly different from 1, therefore conclude that discriminant validity in the study is established. Also, (See Table 2) all indicator loadings except for two items that closely approximate 0.70 are greater than the 0.70 stipulated threshold, suggesting the content validity of the construct. Please, note that the two items were not deleted from the study to enhance the content validity. Composite reliability (CR) indexes (See Table 2) are above the 0.70 recommended in literature as the values range from 0.890 to 0.946 , suggesting that the constructs measures exhibit enough levels of internal consistency reliability. In Table 2, average variance extracted (AVE) for KMI is 0.576 , KMP is 0.567 , IAP is 0.623 and 0.576 for OP. Since all the AVE values are above the 0.50 stipulated threshold for convergent validity, this indicates a high level of convergent validity for the items in the four constructs. As all the 
measurement model shows high reliability and validity of the construct measures, thus provide support for the suitability of the construct inclusion in the structural model for onward assessment.

Figure 2: The research measurement model

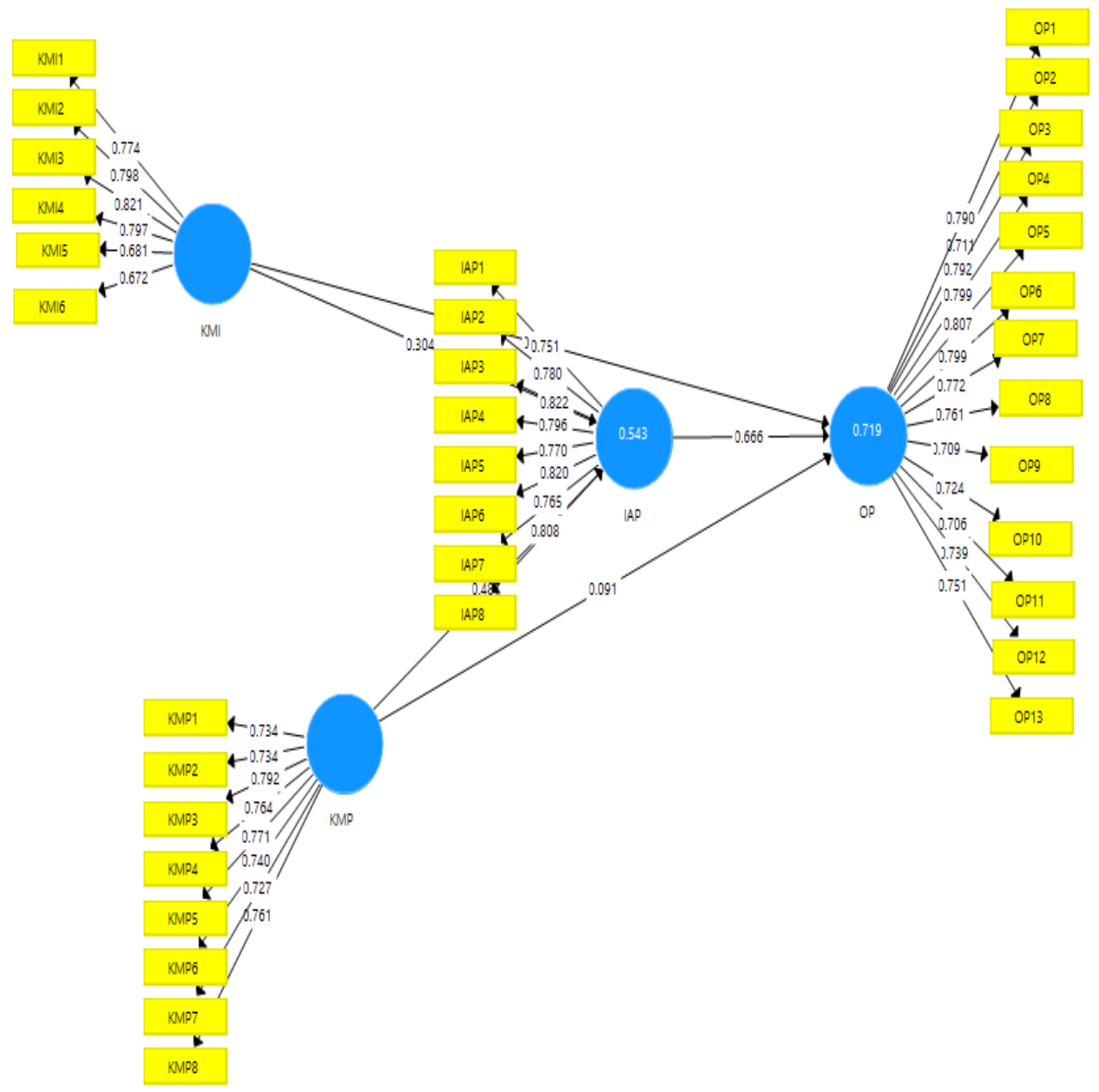

Table 1: Heterotrait-Monotrait (HTMT) summary

\begin{tabular}{llll}
\hline \hline Model construct & IAP & KMI & KMP \\
\hline KMI & $0.734(0.659,0.802)$ & & \\
KMP & $0.776(0.712,0.829)$ & $0.822(0.762,0.878)$ & \\
OP & $0.896(0.859,0.926)$ & $0.731(0.663,0.796)$ & $0.731(0.648,0.803)$ \\
\hline \hline
\end{tabular}

Note: The values in the brackets represent the lower and the upper bounds of the $95 \%$ confidence interval 
Table 2: Result summary of the measurement model assessment on reliability and validity

\begin{tabular}{|c|c|c|c|c|c|}
\hline Model Construct & $\begin{array}{l}\text { Measurement } \\
\text { item }\end{array}$ & Loadings & $\begin{array}{l}\text { Composite } \\
\text { Reliability }\end{array}$ & AVE & HTMT \\
\hline \multirow{8}{*}{$\begin{array}{l}\text { Institutional accounting } \\
\text { practice (IAP) }\end{array}$} & IAP1 & 0.751 & 0.93 & 0.623 & supported \\
\hline & IAP2 & 0.78 & & & \\
\hline & IAP3 & 0.822 & & & \\
\hline & IAP4 & 0.796 & & & \\
\hline & IAP5 & 0.77 & & & \\
\hline & IAP6 & 0.82 & & & \\
\hline & IAP7 & 0.765 & & & \\
\hline & IAP8 & 0.808 & & & \\
\hline \multirow{6}{*}{$\begin{array}{l}\text { KM infrastructure } \\
\text { capability (KMI) }\end{array}$} & KMI1 & 0.774 & 0.89 & 0.576 & supported \\
\hline & KMI2 & 0.798 & & & \\
\hline & KMI3 & 0.821 & & & \\
\hline & KMI4 & 0.797 & & & \\
\hline & KMI5 & 0.681 & & & \\
\hline & KMI6 & 0.672 & & & \\
\hline \multirow{8}{*}{$\begin{array}{l}\text { KM process capability } \\
\text { (KMP) }\end{array}$} & KMP1 & 0.734 & 0.913 & 0.567 & supported \\
\hline & KMP2 & 0.734 & & & \\
\hline & KMP3 & 0.792 & & & \\
\hline & KMP4 & 0.764 & & & \\
\hline & KMP5 & 0.771 & & & \\
\hline & KMP6 & 0.74 & & & \\
\hline & KMP7 & 0.727 & & & \\
\hline & KMP8 & 0.761 & & & \\
\hline \multirow{13}{*}{$\begin{array}{l}\text { Organization } \\
\text { performance (OP) }\end{array}$} & OP1 & 0.79 & 0.946 & 0.576 & supported \\
\hline & OP10 & 0.724 & & & \\
\hline & OP11 & 0.706 & & & \\
\hline & OP12 & 0.739 & & & \\
\hline & OP13 & 0.751 & & & \\
\hline & $\mathrm{OP} 2$ & 0.711 & & & \\
\hline & $\mathrm{OP} 3$ & 0.792 & & & \\
\hline & OP4 & 0.799 & & & \\
\hline & OP5 & 0.807 & & & \\
\hline & OP6 & 0.799 & & & \\
\hline & OP7 & 0.772 & & & \\
\hline & OP8 & 0.761 & & & \\
\hline & OP9 & 0.709 & & & \\
\hline
\end{tabular}

\subsection{Evaluation of the structural model}

\subsubsection{Model's predictive power and relevance}

The coefficient of determination $\left(\mathrm{R}^{2}\right)$ is used to measure the model's predictive power or explained variance in the study. The result (See Table 3) suggests that in the research model, the knowledge management process and knowledge management infrastructure capability explain $54.3 \%$ of the variance in institutional accounting practice (IAP). Also, the result indicates that KM infrastructure 
capability, KM process capability, and institutional accounting practice explains $71.9 \%$ of the variance in organization performance (OP). Since the percentage of variance described by the model is more than that of error, going by this criterion, the research model establishes strong predictive power. In addition to evaluating the magnitude of the $\mathrm{R}^{2}$ values as a criterion of predictive power, Hair Jr et al. (2016) opined that researchers should examine the Stone-Geisser's $\left(\mathrm{Q}^{2}\right)$ value as an indicator of the model's predictive relevance. Table 3 indicated that all the $\mathrm{Q}^{2}$ values are considerably above the stipulated threshold of zero, thus, providing support for the study model's strong predictive relevance. In Table 4, the highest VIF value of 2.587 in the study is clearly below the threshold value of 5, suggesting that there is no multicollinearity issue. Hence, the results of the tested relations are extricated next.

Table 3: $\mathrm{R}^{2}$ and $\mathrm{Q}^{2}$ values

\begin{tabular}{ccc}
\hline \hline Endogenous construct & $\mathrm{R}^{2}$ & $\mathrm{Q}^{2}$ \\
\hline IAP & 0.543 & 0.313 \\
OP & 0.719 & 0.382 \\
\hline \hline
\end{tabular}

Table 4: Assessment of multicollinearity

\begin{tabular}{cccc}
\hline $\begin{array}{c}\text { Institutional accounting practice (IAP) as } \\
\text { the dependent variable }\end{array}$ & \multicolumn{2}{c}{$\begin{array}{c}\text { Organization performance (OP) as the } \\
\text { dependent variable }\end{array}$} \\
\hline Vonstructs & VIF & Constructs & VIF \\
& & IAP & 2.187 \\
KMI & 2.067 & & 2.269 \\
KMP & 2.067 & & 2.587 \\
& & \\
\hline \hline
\end{tabular}

\subsubsection{Hypotheses testing (Direct Effects)}

Table 5 indicates the structural model result is covering direct, indirect, total effects, and the $f 2$ effect sizes. KMI had significant positive influence on organization performance (OP) $(\beta=0.157$, $\mathrm{t}$-value $=2.935, \mathrm{p}<0.05$ ), supporting $\mathrm{H} 1$ (Table 5). The coefficients of the direct path of $\mathrm{H} 1$ is statistically significant and the bootstrap confidence interval, which provides information on the stability of the coefficient estimate, did not include the value of zero. Not supported is $\mathrm{H} 2$ that suggest a positive influence of KMP on organization performance. This is because the $p$ value is not statistically significant at 0.05 level. The reason may be that KMP is having differential impact on OP. Thus, supported by the data for the hypothesized direct relationships using the knowledgebased theory is $\mathrm{HI}$ except $\mathrm{H} 2$ (the direct path of KMP -> OP). The $f 2$ effect sizes measure the impact of the omission of a specific direct predictor construct on an endogenous latent construct, and the threshold is small (0.02), medium (0.15), and large (0.35) based on literature (Hair Jr et al., 2017). In this study (See Table 5), the effect sizes for the direct relationships are within the small range, thus substantivizes their impact on the respective endogenous constructs.

\subsubsection{Hypotheses testing (Indirect effect and mediation analysis)}


In Table 5 below, it is important to note that all the specific indirect effects are significant and the same with the total indirect effect. Thus, the indirect result signifies that the total indirect effects do not contain other indirect effects. From Table 5, the indirect effect of KMI on OP via IAP is significant $(\mathrm{p}=0.000$, Beta $=0.202, \mathrm{t}=4.196)$ at $5 \%$ significant level. Also, the direct effect of KMI on OP is also significant with a p-value of 0.002, Beta $=0.157$. Since the indirect effect and the direct effect are both significant and point in the same direction including the product of the direct and indirect effect (i.e., $0.157 * 0.202=0.032$ ), this is a complementary (partial) mediation (Hair Jr et al., 2017). That is, higher levels of KMI would increase OP directly but also increase IAP, which in turn leads to OP, thus providing support for H3. The implication is that IAP represents a medium that underlies the relationship between KMI and OP. Thus, the result further provides support that IAP mediates the relationship between KMI and OP using the KBT that suggest resources can mediate the influence of knowledge input resource on an outcome.

Also, in Table 5 below, the indirect effect of KMP on OP via IAP is significant $(\mathrm{p}=0.000$, Beta $=$ $0.325, \mathrm{t}=6.649$ ) at $5 \%$ significant level while the direct impact of KMP on OP is not significant with a p-value of 0.08 , Beta $=0.091$, and $t$ value of 1.335 . That is, a unit increase in KMP will somewhat increase organizational performance indirectly via institutional accounting practice, all things being equal. The implication is that IAP represents a medium that fully underlies the relationship between KMP and OP in accordance with the KBT as stated in H4. Since only the indirect impact is significant, it is indirect-only (full) mediation. That is IAP as an indirect only mediating construct, accounts for all the observed relationship between KMP and OP. The result is consistent with KBT which indicate that knowledge-based process influence on an outcome can be mediated.

Table 5: Summary of PLS structural model results

\begin{tabular}{|c|c|c|c|c|c|c|}
\hline $\begin{array}{l}\text { Hypothesized } \\
\text { Relationship }\end{array}$ & $\begin{array}{c}\text { Path } \\
\text { coefficient } \\
(\beta)\end{array}$ & t-value & p-value & $\begin{array}{c}95 \% \text { Bca } \\
\text { confidence } \\
\text { interval }\end{array}$ & $\begin{array}{c}\text { Significance } \\
(\mathbf{p}<0.05)\end{array}$ & $\begin{array}{c}\mathbf{f}^{2} \text { effect } \\
\text { size }\end{array}$ \\
\hline $\begin{array}{l}\text { Direct } \\
\text { H1: KMI -> } \\
\text { OP }\end{array}$ & 0.157 & 2.935 & 0.002 & {$[0.07,0.247]$} & Yes & 0.038 \\
\hline $\begin{array}{l}\text { H2: KMP -> } \\
\text { OP }\end{array}$ & 0.091 & 1.355 & 0.088 & {$[-0.023,0.201]$} & No & 0.011 \\
\hline $\begin{array}{l}\text { Specific } \\
\text { indirect }\end{array}$ & & & & & & \\
\hline $\begin{array}{l}\text { H3: KMI -> } \\
\text { IAP -> OP }\end{array}$ & 0.202 & 4.196 & 0 & {$[0.124,0.282]$} & Yes & \\
\hline $\begin{array}{l}\text { H4: KMP -> } \\
\text { IAP -> OP }\end{array}$ & 0.325 & 6.649 & 0 & {$[0.251,0.41]$} & Yes & \\
\hline Total indirect & & & & & & \\
\hline KMI -> OP & 0.202 & 4.196 & 0 & {$[0.124,0.282]$} & Yes & \\
\hline KMP -> OP & 0.325 & 6.649 & 0 & {$[0.251,0.41]$} & Yes & \\
\hline
\end{tabular}




\section{DISCUSSION}

The research extends the knowledge-based theory (KBT) to explore the role of institutional accounting practice mechanisms in the relationship between KM capabilities (infrastructure and process) and organization performance. The underlying logic behind the KBT as utilized in this research is that there exists a direct and indirect relationship between knowledge input resource, knowledge process resource and outcome. Compared to KM process, KM infrastructure capability has a profound positive influence on overall institutional performance. The reason may be that in KBOs, the capacity of knowledge related infrastructures to influence organizations' performance is directly more emphasized. The implication is that possible benefits associated with KM process capability is underutilized. On the other hand, it is possible that KM process capability mode of impact on the KBOs performance is not direct as evidenced in the research. Thus, the study recommends the design of KM capabilities to fit into the organization context and continuous reassessments of KM initiatives for more KM advantages as generalized KM mechanisms might not be the optimal strategy.

The research reveals that approximately $54.3 \%$ substantial differences in accounting function capacity to give relevant required information, are explained by both KMI and KMP. The finding corroborates and contributes to literature (Appelbaum et al., 2017; Abdel-Kader \& Luther, 2008; Olaisen \& Revang, 2018; Shang \& Seddon, 2000; Spathis \& Ananiadis, 2005) that emphasizes that KM positively influences the financial information capacity in organizations. Interestingly, besides KM capabilities partly explaining the variableness in institutional accounting information system (Ayodele et al., 2019), accounting information system greatly enables KM influence on organization performance. That is, emphasizing employee knowledge development in corporate $\mathrm{KM}$ plan can assist management accountants in their responsibility of planning and controlling the resources of the business. Invariably, KM is beneficial to institutional management accounting practices. The improved functioning of institutional management accounting practices would in turn increase the KBO operational efficiency and managerial decision making (Abdel-Kader \& Luther, 2008; Tilahun, 2019). Thus, the study recommends that managers should promote continuous essential on the job staff expertise training, learning, development, and emphasize knowledge related processes to enhance accounting capacity to give quality information that would influence the institutional performance in the long term and short-term basis. As the research is centred on practice and agrees with the knowledge-based theory, the study adds to the practical implementation of KM in knowledge-based organizations using the KBT.

Also, the study opined that KM impact on organization performance can be reinforced and boosted by augmenting the level of institutional accounting practices. The study, therefore, contributes to studies that emphasize accounting as mediums through which overall institutional goals are attained (Appelbaum et al., 2017; Hackman \& Morris, 1975; Tsahurudu \& Carnegie, 2018). The practical implication is that management should make KM (infrastructure and process) policies to positively affect institutional accounting practices as this will, in turn, help them make better financial and non-financial decisions and react more swiftly to continuously changing competitive conditions. Furthermore, practitioners should optimize the indirect influence of KM capabilities (infrastructure and process) on knowledge-based institutional performance to get a more strategic advantage in their KM plan. As institutions are not well-informed empirically prior now on the KM perspective that would enhance the output of their sophisticated accounting practices, this research, therefore, informs practice that KM with the focus on staff competency and process 
strategy would positively contribute to explain the information output of institutional accounting practices and, consequently the performance of institutions.

Furthermore, the study shows that institutional accounting practice fully mediates the influence of KM process capability on organization performance and partially for KM infrastructure capability influence on organizational performance. That is, an increase in KM infrastructure directly and indirectly influences institutional performance while an increase in KM process would only indirectly influences institutional performance. As the study employs KBT theory in hypothesizing the mediating relationships, the study contributes to KBT that indicate that there exists an indirect and mediating relationship between knowledge input resource, knowledge-based process, and outcome. The resulting mediating effect of institutional accounting practices is not surprising as accounting plays an important mediating role in the realization of organizational objectives (Appelbaum et al., 2017). Moreover, the overall institutional processes are designed to conform with institutional accounting practice mechanisms. The partial and full mediating effect of institutional accounting practices additionally portrays that institutional accounting practice represents an appropriate mechanism to explain the relationship between KM capability and organization performance. Surprisingly, it is sparse if organization present KM strategies are consciously designed to tap into the role played by accounting in KM success. Thus, this research recommends the development of $\mathrm{KM}$ initiatives tailored to harness and foster the capacity of institutional accounting practice to enable and contribute to the success of KM strategy in organizations.

Overall, the study findings are consistent with the KBT underlying logic. This study, therefore, contributes theoretically to KBT and to prior KM literature (Grant, 1996; Sveiby, 2001; Mills \& Smith, 2011; Nieves \& Haller, 2014; Hitt et al., 2016; Nonaka et al., 2018). The theoretical implication is that KBT capability perspective can provide a rich resource for developing concepts and empirically based studies of why and how accounting underlies specific KM capabilities influence on the performance of knowledge-based institutions in Malaysia.

\section{CONCLUSION AND FUTURE RESEARCH DIRECTION}

This research expands upon prior KM literature in a novel way by assessing the role played by institutional accounting practices in the association between specific KM capabilities and organizational performance. The results of the study did not only indicate support for KM as significant predictors of organizational performance, but it also bolsters accounting as a practice that underlies knowledge-based corporate KM action. As organizations are not aware of the real implication of business accounting practices in KM agenda, this study creates the knowledge and awareness of the neglected contribution of institutional accounting mechanisms to KM success. Thus, the research serves as new evidence on which KBO practitioners can base their future institutional KM decisions. Although the study provides an empirical blueprint on the linkage between KM, institutional accounting practices, and overall institutional performance, the research should be interpreted with caution. The study considered only the perception of the staff of largely populated knowledge-based organizations in the measurement of the dependent and independent variables. Thus, future research should incorporate the opinion of employees in other organizations to gain a holistic view and validate the findings in different settings. As context influences research results, the findings can only be generalized to knowledge-based organizations having similar 
social-cultural characteristics and management accounting practices obtainable in Malaysia. Also, this study analyzed the dependent and independent variables at the decomposed level solely based on purposive sampling. In the future, a higher level of analysis based on random sampling may be considered to enhance the extrapolation capability of the findings to other settings and decisionmaking at such a composed level.

\section{REFERENCES}

Abdel-Kader, M., \& Luther, R. (2008). The impact of firm characteristics on management accounting practices: A UK-based empirical analysis. British Accounting Review, 40(1), 2 27. https://doi.org/10.1016/j.bar.2007.11.003

Abu Taber, T. A., Alaryan, L. A., \& Abu Haija, A. A. (2014). The effectiveness of accounting information systems in Jordanian private higher education institutions. International Journal of Accounting and Financial Reporting, 4(1), 28-42. https://doi.org/10.5296/ijafr.v4i1.5323

Al-Emran, M., Mezhuyev, V., Kamaludin, A., \& Shaalan, K. (2018). The impact of knowledge management processes on information systems: A systematic review. International Journal of Information Management, 43, 173-187. https://doi.org/10.1016/j.ijinfomgt.2018.08.001

Alavi, M., \& Leidner, D. (2001). Review: Knowledge Management and Knowledge Management Systems : Conceptual Foundations and Research Issues. MIS Quarterly, 25(15), 107-136.

Andreeva, T., \& Kianto, A. (2012). Does knowledge management really matter? Linking knowledge management practices, competitiveness and economic performance. Journal of Knowledge Management, 16(4), 617-636.

Appelbaum, D., Kogan, A., Vasarhelyi, M., \& Yan, Z. (2017). Impact of business analytics and enterprise systems on managerial accounting. International Journal of Accounting Information Systems, 25, 29-44. https://doi.org/10.1016/j.accinf.2017.03.003

Ayodele, F. O., Yao, L., Haron, H. B., \& Dabor, E. L. (2019). Knowledge Management and Institutional Accounting Functional Effectiveness: Evidence from Malaysia. Journal of $\begin{array}{llll}\text { Information } \quad \& \quad \text { Knowledge } & \text { Management, } & 18(2), & \end{array}$ https://doi.org/10.1142/S0219649219500175

Ball, R., \& Brown, P. (2013). An Empirical Evaluation of Accounting Income Numbers. In S. A. Jeff (Ed.), Financial Accounting and Equity Markets: The Selected Essays of Philip Brown (pp. 27-46). https://doi.org/10.4324/9780203067024

Cepeda, G., \& Vera, D. (2007). Dynamic capabilities and operational capabilities: A knowledge management perspective. Journal of Business Research, 60(5), 426-437.

Cuganesan, S., Dunford, R., \& Palmer, I. (2012). Strategic management accounting and strategy practices within a public sector agency. Management Accounting Research, 23(4), 245260.

Darroch, J. (2005). Knowledge management, innovation and firm performance. Journal of Knowledge Management, 9(3), 101-115. https://doi.org/10.1108/13673270510602809

Eréndira, F. M., Rigoberto, G. C., \& Minerva, M. Á. (2017). Organizational Performance: the mediating effect of the knowledge sharing. OBETS. Revista de Ciencias Sociales, 12(1), 169-189. https://doi.org/10.14198/OBETS2017.12.1.07

Fagbemi, Temitope Olamide., \& Olaoye, J. A. (2016). An Evaluation Of Accounting Information System And Performance Of Small Scale Enterprises In Kwara State, Nigeria. DBA African Management Review, 6(1), 1-16.

Fan, Z. P., Feng, B., Sun, Y. H., \& Ou, W. (2009). Evaluating knowledge management capability 
of organizations: A fuzzy linguistic method (vol 36, pg 3346, 2009). Expert Systems with Applications. https://doi.org/DOI 10.1016/j.eswa.2008.12.059

Gold, A. H., Malthora, A., \& Segars, A. H. (2001). Knowledge Management: An Organizational Capabilities Perspective. Journal of Management Information Systems, 18(1), 185-214. https://doi.org/10.1002/ceat.201000522

Grabski, S. V, Leech, S. A., \& Schmidt, P. J. (2011). A Review of ERP Research: A Future Agenda for Accounting Information Systems. Journal of Information Systems, 25(1), 37-78. https://doi.org/10.2308/jis.2011.25.1.37

Grant, R. M. (1996). Toward a Knowledge-Based Theory of the Firm. Strategic Management Journal, 17(Special Issue: Knowledge and the Firm), 109-122. https://doi.org/10.1002/smj.4250171110

Guzzo, R. a, \& Dickson, M. W. (1996). Teams in organizations: recent research on performance and effectiveness. Annual Review of Psychology, 47, 307-338. https://doi.org/10.1146/annurev.psych.47.1.307

Hackman, J. R., \& Morris, C. G. (1975). Group Tasks, Group Interaction Process, and Group Performance Effectiveness: A Review and Proposed Integration1. Advances in $\begin{array}{lllll}\text { Experimental Social } & \text { Psychology, } & 8, & 45-99 .\end{array}$ https://doi.org/http://dx.doi.org/10.1016/S0065-2601(08)60248-8

Hair Jr, J. F., Hult, G. T. M., Ringle, C. M., \& Sarstedt, M. (2016). Partial Least Squares Structural Equations Modeling ( PLS-SEM ). Thousand Oaks: SAGE.

Hair Jr, J. F., Hult, G. T. M., Ringle, C. M., \& Sarstedt, M. (2017). A Primer on Partial Least Squares Structural Equation Modeling ( PLS-SEM ) ( $2^{\text {nd }}$ ed.). Los Angeles: SAGE.

Hair Jr, J. F., Sarstedt, M., Hopkins, L., \& Kuppelwieser, V. G. (2014). Partial least squares structural equation modelling (PLS-SEM) An emerging tool in business research. European Business Review, 26(2), 106-121.

Henseler, J., Ringle, C. M., \& Sarstedt, M. (2015). A new criterion for assessing discriminant validity in variance-based structural equation modeling. Journal of the Academy of Marketing Science, 43(1), 115-135. https://doi.org/10.1007/s11747-014-0403-8

Hitt, M. A., Xu, K., \& Carnes, C. M. (2016). Resource based theory in operations management research. Journal of Operations Management, 41, 77-94. https://doi.org/10.1016/j.jom.2015.11.002

Howieson, B. (2003, June). Accounting practice in the new millennium: Is accounting education ready to meet the challenge? British Accounting Review, 35, 69-103.

Kanellou, A., \& Spathis, C. (2011). Accounting Benefit and Satisfaction in an ERP Environtment. Proceeding of 8th International Conference on Enterprise Systems, Accounting and Logistic, (July), 360-376.

Karadsheh, L., Mansour, E., Alhawari, S., Azar, G., \& El-Bathy, N. (2009). A Theoretical Framework for Knowledge Management Process: Towards Improving Knowledge Performance. Communications of the IBIMA. https://doi.org/ISSN 1943-7765

Lee, H., \& Choi, B. (2003). Knowledge management enablers, processes, and organizational performance: An integrative view and empirical examination. Journal of Management Information Systems, 20(1), 179-228. https://doi.org/10.2307/40398621

Lee, Y.-C., \& Lee, S.-K. (2007). Capabilities, processes, and performance of knowledge management: A structural approach. Human Factors and Ergonomics in Manufacturing \& Service Industries. https://doi.org/10.1002/hfm.20065

Lin, H.-F. (2014). A multi-stage analysis of antecedents and consequences of knowledge management evolution. Journal of Knowledge Management, 18(1), 52-74. 
Lin, Y., \& Wu, L. Y. (2014). Exploring the role of dynamic capabilities in firm performance under the resource-based view framework. Journal of Business Research, 67(3), 407-413. https://doi.org/10.1016/j.jbusres.2012.12.019

Liu, Y., \& Abdalla, A. N. (2013). Evaluating the managerial behavior of managing knowledge in Chinese SMEs. Information Technology and Management, 14(2), 159-165. https://doi.org/10.1007/s10799-013-0157-X

López-Nicolás, C., \& Meroño-Cerdán, Á. L. (2011). Strategic knowledge management, innovation and performance. International Journal of Information Management, 31(6), 502-509. https://doi.org/10.1016/j.ijinfomgt.2011.02.003

Low, K. Y. J., \& Ho, E. Y. C. (2016). A Knowledge-based Theory of the Multinational Economic Organization. Long Range Planning, 49(6), 641-647. https://doi.org/10.1016/j.lrp.2015.12.004

Mao, H., Liu, S., Zhang, J., \& Deng, Z. (2016). Information technology resource, knowledge management capability, and competitive advantage: The moderating role of resource commitment. International Journal of Information Management, 36(6), 1062-1074. https://doi.org/10.1016/j.ijinfomgt.2016.07.001

Martín-de Castro, G. (2015). Knowledge management and innovation in knowledge-based and high-tech industrial markets: The role of openness and absorptive capacity. Industrial Marketing Management, 47, 143-146. https://doi.org/10.1016/j.indmarman.2015.02.032

Masa'deh, R., Shannak, R., Maqableh, M., \& Tarhini, A. (2017). The impact of knowledge management on job performance in higher education: The case of the University of Jordan. Journal of Enterprise Information Management, 30(2), 244-262. https://doi.org/10.1108/JEIM-09-2015-0087

Mills, A. M., \& Smith, T. A. (2011). Knowledge management and organizational performance: a decomposed view. Journal of Knowledge Management, 15(1), 156-171. https://doi.org/10.1108/13673271111108756

Moon, H., \& Lee, C. (2014). The Mediating Eff ect of Knowledge-Sharing Processes on Organizational Cultural Factors and Knowledge Management Eff ectiveness. Performance Improvement Quarterly, 26(4), 25-52. https://doi.org/10.1002/piq

Nieves, J., \& Haller, S. (2014). Building dynamic capabilities through knowledge resources. Tourism Management, 40, 224-232. https://doi.org/10.1016/j.tourman.2013.06.010

Nonaka, I., Nishihara, A. H., \& Kawada, H. (2018). Knowledge-Based Management Theory. In A. H. Nishihara, M. Matsunaga, I. Nonaka, \& K. Yokomichi (Eds.), Knowledge Creation in Public Administrations: Innovative Government in Southeast Asia and Japan. https://doi.org/10.1007/978-3-319-57478-3_1

Olaisen, J., \& Revang, O. (2018). Exploring the performance of tacit knowledge: How to make ordinary people deliver extraordinary results in teams. International Journal of Information Management, 43, 295-304. https://doi.org/10.1016/j.ijinfomgt.2018.08.016

Ozdil, E., \& Hoque, Z. (2017). Budgetary change at a university: A narrative inquiry. British Accounting Review, 49(3), 316-328. https://doi.org/10.1016/j.bar.2016.09.004

Pandey, S. C., \& Dutta, A. (2013). Role of knowledge infrastructure capabilities in knowledge management. Journal of Knowledge Management, 17(3), 435-453. https://doi.org/10.1108/JKM-11-2012-0365

Pee, L. G., \& Kankanhalli, A. (2016). Interactions among factors influencing knowledge management in public-sector organizations: A resource-based view. Government Information Quarterly, 33(1), 188-199. https://doi.org/10.1016/j.giq.2015.06.002

Ramachandran, S. D., Chong, S., \& Wong, K. (2013). Knowledge management practices and 
enablers in public universities: a gap analysis. Campus-Wide Information Systems, 30(2), 76-94. https://doi.org/10.1108/10650741311306273

Ramjeawon, P. V., \& Rowley, J. (2017). The Learning Organization Knowledge management in higher education institutions: enablers and barriers in Mauritius Knowledge management in higher education institutions: enablers and barriers in Mauritius. Journal of Enterprise Information Management, 24(5), 366-377. https://doi.org/10.1108/TLO-03-2017-0030

Sarstedt, M., Ringle, C. M., \& Hair Jr, J. F. (2017). Partial Least Squares Structural Equation Modeling. In C. Homburg, M. Klarmann, \& A. Vomberg (Eds.), Handbook of Market Research (pp. 1-40). https://doi.org/10.1007/978-3-319-05542-8_15-1

Shang, S., \& Seddon, P. B. (2000). A Comprehensive Framework for Classifying the Benefits of ERP Systems. Americas Conference on Information Systems (AMCIS 2000 Proceedings), 1-11 Paper 39. Retrieved from http://aisel.aisnet.org/amcis 2000

Shang, S., \& Seddon, P. B. (2002). Assessing and managing the benefits of enterprise systems: the business manager's perspective. Info Mation Systems Journal, 12, 271-299.

Sirmon, D. G., Gove, S., \& Hitt, M. A. (2008). Resource management in dyadic competitive rivalry: The effects of resource bundling and deployment. Academy of Management Journal, 51(5), 919-935. https://doi.org/10.5465/AMJ.2008.34789656

Spathis, C, \& Ananiadis, J. (2005). Assessing the benefits of using an enterprise system in accounting information and management. Journal of Enterprise Information Management, 18(2), 195-210. https://doi.org/10.1108/17410390510579918

Spathis, Charalambos, \& Ananiadis, J. (2004). The accounting system and resource allocation reform in a public university. International Journal of Educational Management, 18(3), 196-204. https://doi.org/10.1108/09513540410527194

Sveiby, K. E. (2001). A knowledge-based theory of the firm to guide in strategy formulation. Journal of Intellectual Capital, 2(4), 344-358. https://doi.org/10.1108/14691930110409651

Tilahun, M. (2019). A Review on Determinants of Accounting Information System Adoption. Science Journal of Business and Management, 7(1), 17-22. https://doi.org/10.11648/j.sjbm.20190701.13

Tsahurudu, E., \& Carnegie, G. (2018). Accounting as a Social and Moral Practice. https://www.ifac.org/global-knowledge-gateway/ethics/discussion/accounting-social-andmoral-practice

Zack, M. H. (2003). Rethinking the knowledge-based organization. MIT Sloan Management Review, 44(4), 67-71.

Zahra, S. A., \& George, G. (2002). Absorptive Capacity: A Review Reconceptualization and Extension. Academy of Management Review, 27(2), 185-203.

Zaied, A. N. H. (2012). An Integrated Knowledge Management Capabilities Framework for Assessing Organizational Performance. International Journal of Information Technology and Computer Science, 4(2), 1-10. https://doi.org/10.5815/ijitcs.2012.02.01

Zheng, W., Yang, B., \& McLean, G. N. (2010). Linking organizational culture, structure, strategy, and organizational effectiveness: Mediating role of knowledge management. Journal of Business Research, 63(7), 763-771.

Zoogah, D. B., Peng, M. W., \& Woldu, H. (2015). Institutions, Resources, and Organizational Effectiveness in Africa. Academy of Management Perspectives, 29(1), 7-31. https://doi.org/10.5465/amp.2012.0033 